\title{
eCommons@AKU
}

November 2006

\section{A Pakistani teacher educator's self-study of teaching self-study research}

Ayesha Bashiruddin

Aga Khan University, Institute for Educational Development, Karachi

Follow this and additional works at: http://ecommons.aku.edu/pakistan_ied_pdck

\section{Recommended Citation}

Bashiruddin, A. (2006). A Pakistani teacher educator's self- study of teaching self-study research. Studying Teacher Education, 2(2), 201-212. 
This article was downloaded by: [INASP - Pakistan (PERI)]

On: 11 September 2012, At: 03:40

Publisher: Routledge

Informa Ltd Registered in England and Wales Registered Number: 1072954 Registered office: Mortimer House, 37-41 Mortimer Street, London W1T 3J H, UK

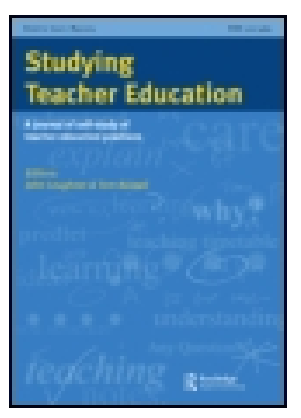

\title{
Studying Teacher Education: A journal of self-study of teacher education practices
}

Publication details, including instructions for authors and subscription information: http:// www.tandfonline.com/loi/ cste20

\section{A Pakistani Teacher Educator's Self-Study of Teaching Self-Study Research}

\author{
Ayesha Bashiruddin ${ }^{a}$ \\ ${ }^{a}$ Aga Khan University, Pakistan \\ Version of record first published: $24 \mathrm{~J}$ an 2007.
}

To cite this article: Ayesha Bashiruddin (2006): A Pakistani Teacher Educator's Self-Study of Teaching Self-Study Research, Studying Teacher Education: A journal of self-study of teacher education practices, 2:2, 201-212

To link to this article: http:// dx. doi.org/ 10.1080/17425960600983221

\section{PLEASE SCROLL DOWN FOR ARTICLE}

Full terms and conditions of use: http://www.tandfonline.com/page/terms-and-conditions

This article may be used for research, teaching, and private study purposes. Any substantial or systematic reproduction, redistribution, reselling, loan, sub-licensing, systematic supply, or distribution in any form to anyone is expressly forbidden.

The publisher does not give any warranty express or implied or make any representation that the contents will be complete or accurate or up to date. The accuracy of any instructions, formulae, and drug doses should be independently verified with primary sources. The publisher shall not be liable for any loss, actions, claims, proceedings, demand, or costs or damages whatsoever or howsoever caused arising directly or indirectly in connection with or arising out of the use of this material. 
Studying Teacher Education

Vol. 2, No. 2, November 2006, pp. 201-212

Routledge

Taylor \& Francis Group

\title{
A Pakistani Teacher Educator's Self- Study of Teaching Self-Study Research
}

\author{
Ayesha Bashiruddin* \\ Aga Khan University, Pakistan
}

\begin{abstract}
This paper describes a teacher educator's self-study of work with her M.Ed. students at a private international university in Pakistan. This systematic inquiry highlights changes and improvements in teaching drawn from experiences of practice based on autobiographies. Analysis shows that improvement in teaching came from the author's learning through self-study. Analysis also reveals implications for teacher educators and teacher education in general.
\end{abstract}

Despite a growing list of scholars who have examined different aspects of self-study of teacher education practices, there is little research concerning the teaching of selfstudy research (SSR). Ben-Peretz (2001) has examined the complexities of the role of teacher educators and identified what she terms as the "impossible role" of the teacher educator in the changing world. Abrahao (2002) revealed the history of Brazilian teacher education in Rio Grande do Sul in southern Brazil using life stories of 12 eminent Brazilian teacher educators. Mueller's (2003) self-study explored how, as a beginning teacher, she cultivated reflective practices for herself and her students as she inquired into her own teaching in an attempt to show "what it means to become a teacher educator" (p. 67).

Some researchers have described the use of self-study in teacher education programs as a tool for reflective analysis through which teachers might develop their practices in teacher education programs (e.g., Ball, 2000; Loughran \& Russell, 1997; Schön, 1983). Others have pointed out that autobiography as a methodology and as a tool for reflection has gained popularity and legitimacy in teacher education curricula following work initiated by Pinar et al. (1995). Others followed with a focus on narrative ways of knowing (Bruner, 1985; Clandinin \& Connelly, 2000; Polkinghorne, 1988) and some researchers have engaged students in writing

^Institute for Educational Development, Aga Khan University, Karimabad, PO Box 13688, Karachi 75950, Pakistan. Email: ayesha.bashiruddin@aku.edu

ISSN 1742-5964 (print)/ISSN 1742-5972 (online)/06/020201-12

(C) 2006 Taylor \& Francis

DOI: $10.1080 / 17425960600983221$ 
autobiographies. Sharkey (2004) drew on the growing field of self-study in teacher education and examined the "role of particular social and political context in the production of autobiographies but also challenges the teacher-educators to reflect on their roles in creating the contexts that affect autobiographical texts" (p. 495), while Elbaz-Luwisch \& Pritzker (2002) described their personal growth as teacher educators and researchers through engaging in a writing workshop in teacher education.

This work can be described as part of a new way of conceptualizing research, yet there appear to be no studies about teaching self-study research within teacher education programs. This paper addresses this gap and is itself grounded in self-study research, thus adding a new dimension to the literature of self-study of teaching and teacher education practices.

\section{Background and Context}

I introduced SSR to two cohorts of M.Ed. classes (70 students in 2004 and 2005) at the Aga Khan University, Institute for Educational Development (AKU-IED), in Karachi, Pakistan in a Teacher Learning course. The students on the course were all experienced teachers from diverse contexts. The Institute for Educational Development of the Aga Khan University was established in 1993 as a teaching, research and policy studies institute. Its goal is to encourage change in the context of "a continued and deepening decline in the quality, effectiveness, relevance and outreach of education systems in Pakistan and elsewhere in the developing world in the face of growing numbers of children and shrinking resources." It admits students not only from Pakistan but also from Bangladesh, Central Asia, East Africa, and India. Its graduate and professional programs are planned and implemented with assistance from its partner universities, that is the Ontario Institute for Studies in Education at the University of Toronto and the Department of Education Studies at the University of Oxford.

For the last 10 years the most commonly used research methodologies introduced to M.Ed. students have been action research and case studies. Introducing SSR in a context where the students were unaware of this methodology was a challenging task. This self-study research has made significant methodological contributions, inaugurating a new domain of experimentation at AKU-IED. Others (e.g., ElbazLuwisch, 2002; Hamilton \& Pinnegar, 1998; Loughran \& Russell, 1997) have used SSR in the West as a teacher learning strategy and this appears to be the first time that that SSR has been introduced in a developing country.

My self-study is based on my experience teaching SSR to students, who were required to investigate their own development as teachers. SSR was introduced through a workshop with two strands-writing autobiography and reflecting on writing. These strands were interwoven through a workshop organized to enable the students to do systematic exploration of their professional development and to analyze that development. Through writing and frequent collaboration with peers, the students were theorizing, although inevitably, the process of theorizing was not linear. 
The goal was a "dynamic interplay between description, reflection, dialogue with self and others" (Johnson \& Golombek, 2002, p. 8). The particular mechanism through which the students theorized included writing stories, sharing and dialoguing with others, identifying patterns, metaphors and images, and engaging in reflection on writing.

\section{Methodology}

I employed self-study research to acknowledge the primacy of experience in developing perceptions and beliefs about improvement of practice. As a researcher/teacher educator, I used a variety of field texts. I collected data from multiple sources and tried to make sense of my teaching and its improvement. Keeping this in the foreground of the inquiry, I used several tools to collect data: my reflective journal, students' reflections on writing, students' evaluation of the course, and students' questions and issues regarding SSR.

\section{Reflective fournal}

The main source of data was my reflective journal. After each session I composed detailed field notes on the computer and gave myself time to analyze them so that I would be ready to change, adjust, or improve my teaching practices. I structured two different tasks for myself to reflect on my practice. One task was to write what I did in the class, to supplement my detailed lesson plan. Using the lesson plan as a basis, I would note some of the details of my teaching, some of the spontaneous changes that I made because of the needs of the students and some of the ways that I clarified tasks. I made amendments in the lesson plan for the next session according to the experience of teaching in the class. I wrote my notes and comments as soon as I finished the workshop session, before they could fade with the passing of time. This provided thinking and reflecting space for me to self-investigate and reflect on my own views regarding effective teaching practices to teach SSR and how those views

changed as a result of teaching the two cohorts of students. I wrote stories of successes, failures, issues, and problems as they emerged.

\section{Students' Reflections on Writing}

Another way of evaluating my own teaching and improving it emerged from students' reflections on writing. There were four inquiry-based tasks in the form of questions that students had to answer at various stages of the writing workshop. They were specifically related to the process of investigation and their professional development through SSR (e.g., What were your experiences of writing about your journey of becoming a teacher and learning to teach? and How would you use this strategy of teacher learning with teachers in your teaching context?). 
Students' Questions Regarding SSR

Because this was the first time that students had explored the self by writing stories of their development as teachers, they asked many questions. Some were asked during workshop sessions and others were asked in tutorial groups. Some of the questions that helped me to reflect on my understanding and teaching of SSR concerned the validity of SSR and the professional significance of their exploration of becoming teachers and writing stories.

At the end of the courses I reviewed and developed 16 themes grouped under three main headings: (1) understanding SSR, (2) conceptualizing ways of teaching, and (3) reflections on the process of teaching and learning. These three themes focused my learning as a teacher educator. Introducing SSR not only enabled students to explore their journeys of becoming teachers but also enabled me to learn from teaching SSR. As a result, I could explore my personal growth, looking at my practices in retrospect and reflecting on my learning from the experiences. Here I discuss my learning from the teaching of SSR under three headings: understanding self-study research, conceptualizing ways of teaching, and reflecting on the process of teaching and learning.

\section{Understanding Self-Study Research}

I became aware of the self-study research when I engaged in it to explore my own development as a teacher (Bashiruddin, 2002). Analyzing that experience enabled me to conceptualize a workshop for my M.Ed. students. Drawing on the experience, I began my own self-study of teaching SSR. A number of factors enabled me to understand and conceptualize SSR as a part of my own professional development.

Firstly, before I was introduced to this genre of research, I believed that knowledge was only generated by experts; however my personal experiences of SSR made me aware of the fact that teachers are knowledgeable persons who can and should understand their own learning. Teachers are thoughtful persons, capable of making decisions and solving teaching problems (Ayers, 1993; Thiessen \& Anderson, 1999). Teachers construct and reconstruct their knowledge through their practice and through reflective analysis of these practices (Britzman, 1991; Clandinin, 1993). Congruent with this belief, I also realized that "research is personal which, quite aside from its social benefits, is worth doing for its direct contribution to one's own selfrealization" (Bullough \& Pinneger, 2001, p. 13).

Secondly, self-study research developed my understanding that writing about self is a "method of inquiry ... a way of knowing - a method of discovery and analysis" (Richardson, 2000, p. 923). I see it as a way of telling about the individual self, as embedded in the social and cultural world. Keeping this understanding in mind, I initiated a writing workshop in which the intention was to encourage students to go through a process of discovery, to find their own voices and identities as teachers. They engaged in a process of writing through which they inquired about their selves. This approach was taken to make writing a dynamic, creative process through which 
the students might develop confidence in writing stories of their development as teachers. For discovering the self through writing, I gave students the latitude to select the ways in which they wanted to represent themselves as teachers.

Thirdly, my personal experiences of SSR support Johnson and Golombek's (2002) description of this self-exploration as professional development: "Thus, we believe that teachers' stories of inquiry are not only about professional development; they are professional development" (p. 6). The process of writing stories of experiences has been identified as a powerful way of encouraging teachers' professional growth in teacher education programs (Kelchtermans, 1993; Raymond, Butt, \& Townsend, 1992) and in improving teacher education practices (Loughran \& Russell, 1997). In conceptualizing the workshop I assumed that the students would bring their ways of knowing and growing into the process of exploring their experience by writing stories. I hoped that the stories would allow them to look into their past and let them grow, because such stories can help to guide participants to plan their future as teachers in their own professional contexts. Also, engaging in the process of writing stories and reflecting on them could enable them "not only to make sense of their professional worlds but also to make significant and worthwhile change within themselves and in their teaching practices" (Johnson \& Golombek, 2002, p. 7). Thus, the aim of introducing students to this kind of inquiry would be to help them to see it as a process of continuous professional growth. The workshop aimed to give students an opportunity to work individually and collaboratively in "a transformative space where diverse voices can find expression” (Elbaz-Luwisch \& Pritzker, 2002, p. 277).

\section{Conceptualizing Ways of Teaching}

My own experience as a researcher and my involvement in self-study research (Bashiruddin, 2002) gave me confidence to introduce my students to these perspectives. I constructed a detailed workshop lesson plan in which I developed my own understanding of what it means to teach self-study research. In order to plan, I had to reflect on my own processes of writing. I recalled the approaches that had helped me in writing, such as brainstorming, writing individually, reading my own stories of experience and reflecting on them, linking stories to establish significance, sharing my stories with others and getting their feedback, and reading published selfstudies. In conceptualizing ways of teaching self-study research, I kept a process-genre approach to teaching writing (Badger \& White, 2000). I tried to incorporate all these ways of exploring and writing about the self. Keeping all this in mind, I organized the workshop to give time and space for the students to write, share, reflect, and read the relevant literature.

Because this was the first time that the students were engaging formally in selfstudy, I was concerned about the quality of their writing. I asked them to read Bullough and Pinnegar's (2001) paper on "Guidelines for quality in autobiographical forms of self-study research." The next day their 14 guidelines for quality in autobiographical forms of self-study research were discussed in class to help students understand and follow them. 
An aspect of SSR that was initially difficult for me to understand involved acknowledging the fact that we as teachers experience critical incidents that have significance in our development. I recognized that my students might as well have similar concerns, and I thought of beginning the process of investigating self by starting the workshop by sharing my own stories of becoming a teacher. I wrote the following in my journal:

I think unless students believe in themselves they would not be able to have confidence in themselves. I think I need to begin small and ask them the first question that is: How did they decide to become teachers? Then allow them time to think and share stories with each other. I also feel that since I have shared my own story I have developed some level of trust. I can read the beginning of my story which describes my dream of becoming a teacher. After that I could ask students to share their stories whoever wished to with the class. (Reflective Journal, 12 May, 2003, p. 5)

Asking students to open up their lives for examination is filled with tensions and can be both threatening and challenging. I thought of asking students to choose partners, with whom they would be comfortable in sharing their stories. I was cognizant of the fact that I was introducing a new way of teaching and learning by engaging the students in self-study and reflections on writing. I planned the integration of the two strands to facilitate their writing as well as help them to reflect at different stages of writing. This generated another concern: given that these were two different types of writing, would it be possible for the students to switch easily from one to another? These concerns were important in leading me to conceptualize the workshop, that is introducing my students to SSR.

\section{Reflecting on the Process of Teaching and Learning}

Self-study provided me with a way to articulate what it was that I was learning about my teaching of SSR within a teacher education program. I monitored my teaching closely and wrote reflections about my learning from the teaching experiences. In my reflective journal I wrote:

As a self-study researcher I was convinced that exploring the developments of my professional life is an important way of learning about myself and about the teaching profession. But it is hard to convince others of the same. I shared my own self-study research and others available in literature. I asked them to think of themselves as researchers and authors of their own lives. (Reflective Journal, 2 June, 2004, p. 22)

This was to acknowledge participants as knowledgeable individuals and to give meaning to my belief that "everyone's voice matters and everyone has something worthy to communicate" (Wood \& Lieberman, 2000, p. 260).

From my first experience of teaching SSR to the M.Ed. class of 2004 I concluded that the students needed more time to read about others and tell stories before they started writing. As I was engaged in practical inquiry, I made immediate changes in 
my teaching. For instance, at this point I asked the students to read SSR in their independent study time. Guided by analysis of this experience, my introduction of the 2005 cohort to SSR included opportunities to read not only teachers' stories from western contexts but also stories of their fellow students from the developing country's contexts (Bashiruddin, 2004). They found the latter more relevant because they could relate more directly to these stories. One student pointed out that reading stories about a teacher developing in a context similar to his own gave him the confidence to explore his own development as a teacher.

Although I had planned ways in which I could encourage students to explore self, as the process of writing and teaching unfolded I realized that, because this was a new concept, many of the students were inexperienced authors at an initial stage of writing. Students expressed concerns about what to write as they felt that they had nothing significant to write about. Thus my first challenge was to help them see how each of us is unique and that we need to acknowledge that our lives, our beliefs, and the ways we develop as teachers have taken considerable time and are worthy of being accounted.

Sharing my belief that teachers themselves can generate knowledge and learn from their own experiences was a significant personal test in my role as teacher educator. At the start of the workshop most students were skeptical because this was the first time that they had encountered SSR. Introducing an innovation in which selfdisclosure is a major ethical concern was a challenge. "Introducing a new activity requires more time, not only in carrying out the activity itself but also in orienting and training the students to perform the new and different task" (Bashiruddin, 2003, p. 249). I recognized two major tasks. One was to convince students that their personal stories were important, given the tendency for teachers to accept knowledge from outside, from books and journals; thus, implicitly devaluing learning from their own experiences. Another was to convince students that they were the authors of their own stories and thus could and should select the stories or critical incidents that they wanted to disclose. My first step was to share my own story of continuous professional development (Bashiruddin, 2002). This helped many to overcome their sense of anxiety, once they also realized that they would be provided with support during their writing.

Through this SSR I fostered reflective practices for myself and for my students. The students were to write reflections on writing that encouraged them to reflect on the writing process. In this way I could examine the learning that occurred during the teaching of the two cohorts and I also gained personal confidence in studying my own teaching practices and my ability to respond to my students' comments throughout the course. I soon realized that it would be useful to ask a colleague to serve as a critical and supportive friend, because "each individual has some expertise, knowledge, or nuanced understanding with the potential to help others" (Wood \& Lieberman, 2000, p. 260). Unfortunately, because of busy teaching schedules, this was not possible.

I struggled constantly with the dilemma of how much support I as a teacher educator should give my students. On the one hand, I wanted to give support and help them with the process of inquiry. When I felt that the question in Task 1 (reflections on writing) was difficult, I helped them to understand it by addressing their concerns 
and by offering examples of ways to respond. I acknowledged their concern that the question was challenging and I shared my reflections with them, as recorded in my journal:

The question in Task 1 was too complicated for the students. Perhaps I should have made it simpler. I think the other problem was switching from actually writing the stories to reflecting on the process of writing. I think I should share my reflections with the students. (Reflective Journal, 20 May, 2003, p. 10)

On the other hand, I wanted to encourage the sense of personal responsibility and freedom that is necessary to explore and write one's own stories. I found myself in a balancing act in which I gave learners the responsibility of constructing, writing, and editing their stories as well as sharing with others their developing autobiographies. I also gave them the responsibility of writing reflections on writing as an individual task to be submitted during the course.

The stories teachers tell about learning to teach and the many ways in which they come to understand these learning-to-teach experiences have always been of immense interest to me as an educator. By reading and reflecting on my students' stories of their own development as experienced teachers, I was able to understand not only the complexities involved in teachers' learning to teach but also my own process of professional development. "The stories we hear and the stories we tell shape the meaning and texture of our lives at every stage and juncture" (Witherell \& Noddings, 1991, p. 1).

The insights and understandings gained from the students' reflections on writing provided me with alternative ways of thinking about conducting the workshop. Thus I could see "my learning to be intertwined with my students' learning. They were teaching me how to be a teacher educator by expressing what they needed to learn as young professionals" (Mueller, 2003, p. 71). These alternative ways of thinking and learning helped me in teaching SSR to the second cohort of students, as I incorporated changes based on reflective analysis of my first experience of teaching.

With the first cohort in 2004, I did not discuss the reflections on writing in detail, especially Task 4 which required the students to reflect whether or not teaching SSR could be effectively employed in developing countries. When I read the responses of the students I realized that it was an important issue to discuss as a whole class. A student from the same class undertook a study in the area as his M.Ed. dissertation (Tamamu, 2004). I invited him to introduce his study to the 2005 cohort to generate discussion regarding the use of SSR in the context of a developing country. This generated interesting discussion and my understanding of research cultures of different countries was broadened.

\section{Implications for Teacher Educators and Teacher Education}

As an individual teacher educator I have gained much from this SSR on teaching SSR to experienced teachers from developing countries. As Russell (2002, p. 83) pointed out, self-study "generates three new audiences." For me, these included: (1) the 
M.Ed. students themselves, who will read about my challenges, issues, and questions in teaching SSR; (2) my colleagues at The Aga Khan University, who may become interested in this genre of research; and (3) other teacher educators, who are examining, reflecting and interpreting their teaching practices in relation to self-study. The importance of SSR is increasingly recognized within developments and changes in understanding approaches to learning to teach in a western context (Loughran, Hamilton, LaBoskey, \& Russell, 2004). Furthermore, this study may be helpful to other teacher educators in both western and non-western contexts, encouraging dialogue between the researcher and the audience:

\footnotetext{
The connection and integration the reader will achieve will come not only as an emergent from a dialogue. They will be marked by what Mikhail Bakhtin called "hetroglossia" (1981): the sound of many discourses, many voices; and the consciousness of a listener or reader affecting what is thought and what is said. ... There is the likelihood of inclusion, the inclusion of those ... who [would] read. (Greene, 1991, p. x)
}

Others (e.g., Hamilton \& Pinnegar, 1998; Loughran \& Russell, 2002) have used selfstudy research in western contexts as a strategy to support teacher learning, but this study represents the first time that such an approach has been introduced in a developing country. This study has inaugurated a new domain of research and experimentation in Pakistan. As a teacher educator I see myself contributing to the reform movement by introducing it to students at AKU-IED. Previously, students have not been involved in this kind of SSR which gives priority to the teacher's voice and thus opens up new ways of understanding teacher development. Therefore, introducing new research paradigms is an important initiative for all teacher educators.

\footnotetext{
Teacher educators need to continuously create spaces within teacher education programs that are dedicated to practicing and to discussing the crucial role of reflection with beginning professionals. Concurrently, when teacher educators engage in dialogue with their colleagues about critical learning experiences, future teachers and teacher educators are enriched personally and professionally. (Mueller, 2003, p. 82)
}

This study suggests that a thoughtful use of SSR integrated into a teacher education program can be a viable and empowering form of professional development for teacher educators and for teachers working to improve their teaching. My personal analysis of the process will shape our strategies for the future. In this respect my selfreflection can be valued as an important activity in the process of developing an SSR workshop and of thinking about exploring how new ways might be developed to facilitate SSR. I have initiated a research study group at AKU-IED considering auto/biography in teacher development. The main goal of the group is to encourage research in the area of auto/biography in teacher development. It seeks to bring together teachers and teacher educators from a wide variety of settings who are interested in various kinds of biography and autobiography, the relationships among different genres of representing text and lives, and interrelationships between biography and autobiography. It also aims to introduce the concept of autobiography 
in teacher development and raise awareness of its effective use in teaching and research. This study group hopes to develop "a new landscape for professional dialogue among teacher educators and between teacher educators and both new and experienced teachers" (Russell, 2002, p. 9). It is providing a forum for teacher educators to make a substantial contribution related to the theory and practice of teacher education, self-study as a research design and practice, and the professional development of teachers and teacher educators. The group includes faculty members and graduate students who are doing a collaborative SSR on "From teachers to becoming teacher educators: Implications for teacher education". Both experienced teachers and teacher educators can benefit from "opportunities to develop capacities for reflection, collaboration, research, critique, and assessment" (Wood \& Lieberman, 2000, p. 256).

As Feldman (2003) has pointed out, "self-study recognizes at least implicitly that to improve our teacher education practices we need to change our ways of being teacher educators" (p. 27). I would add that as teacher educators we need to support each other in implementing new practices. Because my workshops were part of a full course on Teacher Learning, I was working in a team. The team members appreciated my efforts to engage students in SSR and provided all the support that I wanted. At the same time they gave me latitude to develop the workshop as I felt appropriate. This way as a teacher educator I realized how important it is to seek support from colleagues who are part of a team.

Innovative ways of teaching can also encourage teacher educators in using students' work as a resource for developing curriculum. As a result of this SSR, I developed an ebook entitled My Story, My Identity: M.Ed. Course Participants' Narratives of Becoming Teachers (Bashiruddin, 2004). From 35 narratives written by students of the class of 2004, I selected six, taking two from each of the three areas represented in the M.Ed. class (East Africa, Central Asia, and Pakistan). After each narrative, I raise critical questions for stimulating reflection and discussion. I used this e-book in teaching the 2005 cohort of M.Ed. students (class of 2005). Thus, this book is an example of a curriculum developed from the knowledge generated by teachers. This, as Tamamu (2004) points out, has encouraged the students whose stories are used in the book and has introduced SSR to the wider audience of students and teacher educators at AKUIED. It is possible, as shown in this study, to introduce SSR into academic environments. Teacher educators can continuously develop curriculum from teachergenerated knowledge and need not depend entirely on outside experts. Such efforts can create an enriched, diversified, and enthusiastic community of self-study researchers.

Becoming involved in SSR has generated important interest among our students. As a supervisor of an M.Ed. dissertation, I worked closely with the author and this helped me understand how SSR can be used as a reflective tool in teacher education programs. The author is from East Africa and, on his return to Tanzania, he has the desire to involve other teachers in similar research:

This was a pioneering study on SSR at AKU-IED. Since the purpose of SSR is to "illuminate rather than confirm and settle" (Bullough \& Pinnegar, 2001, p. 20), I hope my study will generate interest and trigger a dialogue that will eventually lead into 
successful adoption of SSR in teacher education. I hope to try out the findings of this study in my own context (Tanzania) and would like to challenge other students to do the same, since this study was just the beginning and not in any way the end. (Tamamu, 2004, p. 75)

I have sown the seeds of SSR and I hope that further work in this area will follow. I have hopes that, because all the students in our M.Ed. program come from diverse backgrounds and countries, they will take these ideas into their own contexts and further develop and adapt them as they see appropriate, thereby extending the community of self-study researchers. I look forward to engaging in dialogue with the wider community of teacher educators who carry out their own SSR.

\section{References}

Abrahao, M. H. M. B. (2002). Brazilian teacher education revealed through the life stories of great educators. Fournal of Education for Teaching, 28(1), 7-16.

Ayers, W. (1993). To teach: The journey of a teacher. New York: Teachers College Press.

Badger, R., \& White, G. (2000). A process genre approach to teaching writing. ELT fournal, 54(2), $153-160$.

Ball, D. (2000). Bridging practices: Intertwining content and pedagogy in teaching and learning to teach. Fournal of Teacher Education, 51, 241-247.

Bashiruddin, A. (2002). Seasons of my learning. In J. Edge (Ed.), Continuing professional development: Some of our perspectives (pp. 104-114). Kent, England: IATEFL.

Bashiruddin, A. (2003). Learning English and learning to teach English: The case for two teachers of English in Pakistan. Unpublished doctoral dissertation, Ontario Institute for Studies in Education. University of Toronto.

Bashiruddin, A. (2004). My story, my identity: M.Ed. course participants' narratives of becoming teachers. Retrieved August 22, 2006, from http://www.eyesha.com/Downloads/EBook.pdf

Ben-Peretz, M. (2001). The impossible role of teacher educators in a changing world. Fournal of Teacher Education, 52, 48-56.

Britzman, D. (1991). Practice makes practice: A critical study of learning to teach. Albany, NY: State University of New York Press.

Bruner, J. (1985). Narrative and paradigmatic modes of thought. In E. Eisner (Ed.), Learning and teaching the ways of knowing. 84th yearbook of the National Society for Study of Education (pp. 97-115). Chicago: University of Chicago Press.

Bullough, R. V., Jr., \& Pinnegar, S. (2001). Guidelines for quality in autobiographical forms of selfstudy research. Educational Researcher, 30(3), 13-21.

Clandinin, D. J. (1993). Teacher education as narrative. In D. J. Clandinin, A. Davies., P. Hogan, \& B. Kennard (Eds.), Learning to teach, teaching to learn (pp. 1-15). New York: Teachers College Press.

Clandinin, D. J., \& Connelly, F. M. (2000). Narrative inquiry: Experience and story in qualitative research. San Francisco, CA: Jossey-Bass.

Elbaz-Luwisch, F. (2002). Writing as inquiry: Storying the teaching self in writing workshops. Curriculum Inquiry, 32, 403-428.

Elbaz-Luwisch, F., \& Pritzker, D. (2002). Writing workshops in teacher education: Making a space for feeling and diversity. Asia-Pacific fournal of Teacher Education, 30, 277-289.

Feldman, A. (2003). Validity and equality in self-study. Educational Researcher, 32(3), 26-28.

Greene, M (1991). Foreword. In C. Witherell, \& N. Noddings (Eds.), Stories lives tell. Narrative and dialogue in education ( $\mathrm{pp}$. ix-xi). New York: Teachers College Press. 


\section{A. Bashiruddin}

Hamilton, M., \& Pinnegar, S. (1998). Conclusion: The value and the promise of self-study. In M. Hamilton (Ed.), Reconceptualizing teaching practice: Self-study in teacher education (pp. 235-246). London: Falmer Press.

Johnson, K. E., \& Golombek, P. R. (2002). Inquiry into experience. In K. E. Johnson, \& P. R. Golombek (Eds.), Teachers' narrative inquiry (pp. 1-14). Cambridge, England: Cambridge Language Education.

Kelchtermans, G. (1993). Getting the story, understanding the lives: From career stories to teachers' professional development. Teaching and Teacher Education, 9, 443-456.

Loughran, J. J., Hamilton, M. L., LaBoskey, V. K., \& Russell, T. (Eds.) (2004). International handbook of self-study of teaching and teacher education practices. Dordrecht, The Netherlands: Kluwer.

Loughran, J., \& Russell, T. (Eds.) (1997). Teaching about teaching: Purpose, passion and pedagogy in teacher education. London: Falmer Press.

Loughran, J., \& Russell, T. (Eds.) (2002). Improving teacher education practices through self-study. London: RoutledgeFalmer.

Mueller, A. (2003). Looking back and looking forward: Always becoming a teacher educator through self-study. Reflective Practice, 4, 67-84.

Pinar, W. F., Reynolds, W. M., Slattery, P., \& Taubman, P. M. (1995). Understanding curriculum: An introduction to the study of historical and contemporary curriculum discourses. New York: Peter Lang.

Polkinghorne, D. (1988). Narrative knowing and the human sciences. Albany, NY: State University of New York Press.

Raymond, D., Butt, R., \& Townsend, D. (1992). Contexts for teacher development: Insights from teachers' stories. In A. Hargreaves, \& M. Fullan (Eds.), Understanding teacher development (pp. 141-161). London: Cassell.

Richardson, L. (2000). Writing, a method of inquiry. In N. K. Denzin, \& Y. S. Lincoln (Eds.), Handbook of qualitative research (pp. 923-948). Thousand Oaks, CA: Sage.

Russell, T. (2002). Guiding new teachers' learning from classroom experience. Self-study of the faculty liason role. In J. Loughran, \& T. Russell (Eds.), Improving teacher education practices through self-study (pp. 3-9). London: RoutledgeFalmer.

Schön, D. A. (1983). The reflective practitioner: How professionals think in action. New York: Basic Books.

Sharkey, J. (2004). Lives stories don't tell: Exploring the untold in autobiographies. Curriculum Inquiry, 34, 495-512.

Tamamu, A. (2004). Self-study research as a teacher learning strategy in teacher education: Perceptions and experiences of Master of education course participants at AKU-IED. Unpublished master's thesis, The Aga Khan University, Institute for Educational Development, Karachi, Pakistan.

Thiessen, D., \& Anderson, S. (1999). Getting into the habit of change in Ohio schools: The cross-case study of 12 transforming learning communities. Columbus, $\mathrm{OH}$ : Ohio Department of Education.

Witherell, C., \& Noddings, N. (Eds.) (1991). Stories lives tell. New York: Teachers College Press.

Wood, D. R., \& Lieberman, A. (2000). Teachers as authors: The National Writing Project's approach to professional development. International fournal of Leadership in Education, 3, $255-273$. 